\title{
Modified proverbs in al-Mạ̣mūd's Novel Muftaraq al-Mațar (The Parting of the Rain)
}

\author{
Huwaida Issa \\ Department of Arabic, Islamic and Middle Eastern Studies \\ University of Leeds, United Kingdom
}

\begin{abstract}
This paper, which develops ideas in my Ph.D. thesis (Issa, 2014), identifies a number of modified proverbs in a modern Arabic novel, Muftaraq al-Mațar, by the Syrian novelist Yūsuf al-Mahmūd. The study delves into how different scholars define modified proverbs (also sometimes referred to as deformed proverbs or anti-proverbs). The researcher will study a sample of adapted proverbs, regarding their new representation, and the effect of formal changes on their meaning, especially, when compared with their original structure. The study focuses on how the use of proverbs in narrative helps to flesh out the material and cultural life of $20^{\text {th }}$ century Syria. This is done mostly by re-contextualizing the adapted proverbs. In so doing, the paper also discusses the different techniques of modification identified by various researchers. Then the focus moves on Alan Partington's (1998, pp.126-8) four techniques for modifying phrases: substitution, insertion, abbreviation, and rephrasing. This is followed by an examination of sixteen modified proverbs, which are classified into four groups, each one representing the implementation of one of Partington's four techniques. Finally, the study examines the semantic effect of applying these techniques.
\end{abstract}

Key words: modified, proverbs, semantics, Syrian, technique

Cites as: Issa, H. (2019). Modified proverbs in al-Mạ̣mūd's Novel Muftaraq al-Mațar (The Parting of the Rain).Arab World English Journal for Translation \& Literary Studies, 3 (1) 257 275. DOI: http://dx.doi.org/10.24093/awejtls/vol3no1.20 


\section{Introduction}

This paper examines the linguistic, semantic and cultural dimensions of a number of modified proverbs in Yūsuf al-Mahmūd's modern Syrian novel, Muftaraq al-Mațar. This is achieved through studying these adapted proverbs in the light of Alan Partington's four techniques for modifying phrases: substitution, insertion, abbreviation and rephrasing (Partington, 1998, pp.1268 ), and subsequently analyzing the semantic effects of these modifications on the new forms of the original proverbs. There are two possible outcomes of such adaptation: it either gives the new proverb an opposite meaning to that of the original, thus setting up an antonymous relationship between the adapted proverb and its original form, or instead it establishes a relationship between the modified proverb and its original form that is synonymous or near-synonymous.

Al-Mahmūd uses modified proverbs to give credibility to his text. This is mainly due to the long history of proverbs, as described by the paremiologist (scholar of proverbs) Wolfgang Mieder (2004, p.xii), who mentions that proverbs are a long-standing cultural device which yields both codes of conduct and anthropological observations. Al-Mahmūd also uses modified proverbs to provide an authentic depiction of Syrian life and culture in the first half of the $20^{\text {th }}$ century, thus giving further credibility to his narrative. Another function of these adapted proverbs is to highlight the specific characteristics of rural Syrian culture, fleshing out the cultural and material life that grounds the narrative. Moreover, the rich background of folkloric elements in Arabic novels, only scantily examined by current scholarship, demonstrates that techniques of adaptation and modification play a vital role in preserving and expanding the cultural roots that inform alMahmūd's narrative. To conclude, proverbs make the narrative feel authentic, and they do so thanks to their enduring authoritative status, their inherent cultural specificity and the depth of the cultural background they implicitly refer to.

\section{Critical context of modified proverbs and their modification techniques}

I will, first of all, analyze the reception and modification of proverbs. Many scholars have studied modified proverbs in connection with theories of literary and cultural traditions, the role of semantics within a dystopian world, and the necessity for proverbs to be adapted in certain contexts. For instance, according to Mieder, modified proverbs (what he terms 'anti-proverbs') are "parodied, twisted, or fractured proverbs that reveal humorous or satirical speech play with traditional proverbial wisdom" (2004, p.28; cf. Mieder, 2003; Mieder \& Litovkina, 1999). Mieder proposes various ways in which proverbs can be changed. One possibility is a slight difference in form between the original proverb and the modified one, as in the example provided by Mieder and Mieder (2004, p.314): "Do unto mothers" instead of "Do unto others". Here the modified proverb has been changed by adding one single letter, but in other cases modified proverbs may deviate drastically from their original form. Therefore, reception is always a matter of adaptation to a new context.

Furthermore, I will analyze how adaptation functions by relying on the old versions of the proverbs and the reader's familiarity with these original forms. Mieder (2004, p.28) emphasizes the importance of the cultural dimension of proverbs for the reader, who seizes upon their original, authentic form in order to figure out the meaning of the new guise in which they sometimes appear

Arab World English Journal for Translation \& Literary Studies 
in the novel. According to Mieder (2004, p.28), it is highly likely that a reader familiar with the cultural background of a novel will identify the original proverb, despite its adaptation, even though, in some cases, a modified proverb may, in fact, convey an opposite meaning to that of the original. In this context, Mieder (2004, p.28), suggests that questioning the original form of the proverb through "adding a contradictory phrase beginning with the conjunction "but" is one way of transforming a proverb. However, this modification or addition does not undermine the importance of the adapted proverb because this changed form is still able to serve a certain function. Mieder notes that with the existence of many transformations of the original proverbs, it is difficult to maintain the idea of the sacredness of the proverbs' frames, forms or stable appearance. As Mieder (2004), argues:

The fixity of proverbs is not as rigid as it once was believed to be. Unintentional variants have also been part of the use and function of proverbs, both oral and written. And yet, more often than not proverbs are cited in their standard traditional form to add some common sense to human communication (p.28).

Overall, the adaptation of proverbs is necessary for them to remain operative in novel contexts.

Martinez (2006), supports Mieder's view about adapting proverbs to operate in certain contexts. In his article "Occasional Phraseological Synonymy” (pp.133-34), Martinez refers to the original, base forms of a phrase as "canonical phraseological units" (p.132), and examines the semantic connection between the original phrase and the adapted one. Martinez proposes that when there is a replacement of one word or more in a proverb, but the meaning remains the same, the new form can be called an "occasional synonymous unit". According to Martinez (2006), "this type of occasional productivity is not directly related with the lexemes that take part in the process of substitution" (pp.133-34). Rather, re-contextualization is the underlying reason for adaptation and transformation. This is highlighted by Martinez, who is interested in studying how a change of lexemes produces a "new synonymous creation" (2006, p.134). He also stresses the importance of the "contextualization of the original unit" (2006, p.134). This means that such a change is determined by the adaptation of the proverb to a new context. However, the original form of the proverb maintains its authority. Martinez (2006, p.134) explains the vitality of the context: "The contextual information is so important that sometimes the interchange of synonymous lexemes in a specific context yields an utterance which is semantically very distant from the original form in a specific context".

A similar view is taken by Naciscione (2001), who refers to the way in which proverbs are re-contextualized or re-written as "instantial use" (p.55). Martin (2011), further articulates this point, taking as an example "the clean sweep of the proverbial new broom" (p.185). In this case, although the structure of the original proverb "a new broom sweeps clean" has been modified, the meaning has not changed. He also points out (2011, p.185), however, that modification may bring about a change in meaning such that the meaning of the modified proverb only to a certain extent overlaps with the canonical meaning of the original proverb. According to Martin (2011, p.185),

Arab World English Journal for Translation \& Literary Studies 
the workings of proverb modification can be summarized as follows. The speaker/writer first of all chooses a canonical proverb with a suitable meaning. Then, she/he alters one or more of its constituents in a way that changes its interpretation in view of its new wording. Nonetheless, the original proverb can still be recognized by hearers/readers, thus making both versions of the proverb overlap. This can be presented as follows: 1) original proverb; 2) new context; 3) semantic shift preserving or altering original meaning (semantic shift but also preservation of the "authority" of the original proverb).

In order to analyze how re-contextualisation causes a semantic shift, various scholars have suggested different interpretive categories. According to Fernando (1996), there are four different ways to transform or adapt a phrase or an idiom: "substitution, addition, permutation and deletion" (p.54). These are explained as follows. Substitution involves exchanging one letter or word for another. Addition involves adding a letter, a word or even a phrase to the original proverb. Permutation involves having the same wording as the original proverb but in a different order. Finally, deletion means subtracting/extracting/removing a part of the original proverb. Partington (1998) similarly identifies four techniques for modifying a phrase: "substitution, insertion, abbreviation and rephrasing" (pp.126-8). In this paper, the researcher will make use of Partington's classification, because it provides a clearer analysis than, for example, Zaikauskiene (2012), who has studied Lithuanian proverbs and their methods of modification, and is also clearer than the classification of Fernando, in fact partially revising Fernando's categories.

As noted, the first modification technique in Partington's classification is a substitution. Partington (1998) defines this as: "homophone-to-heterograph or single phoneme alteration[s]" (p.126). Partington (1998) explains this further as follows: "one of the items of the original collocation is replaced by another, but the replacement must not change the phrase so drastically as to make the original unrecognizable to the text receiver" (p.126). Partington (1998) provides the following example: "Prints Charming' for 'Prince Charming"” (p.126). He (1998) explains that there are two types of substitution: "whole-word substitution" (p.126) and "grammatical substitution" (p.126). He (1998) provides the following example, which illustrates both types: "Murder of the cathedral" (p.126) for "Murder in the Cathedral" (p.126) (a verse play by T.S. Eliot). Here, replacing a whole word also entails a grammatical change. Likewise, Zaikauskienè (2012) states that substitution may entail a minor change in the original proverb. Such a shift, which does not affect the overall meaning of the canonical proverb (paremia), will generate a modified proverb, which is a variant of the original, basic proverb.

Partington's second modification technique is insertion, which occurs whenever "an element has been added to the original". Partington (1998, p.127), exemplifies this as follows: "'Play up and play the word game' [is the adapted form of the original phrase] 'Play up and play the game"". According to Zaikauskiene (2012), similarly, the most popular way of creating Lithuanian modified proverbs (anti-paremias) is a combination of equal lexical substitution (in the case of two-part proverbs) plus extension of the traditional paremia by a comment or reference i.e. insertion, in Partington's terms. Later in this paper, the researcher will present examples of the 
modified proverbs which use Partington's insertion technique (Zaikauskienè's extension technique).

Partington's third modification technique is an abbreviation. This occurs whenever only part of the original proverb or traditional phrase is reproduced. Partington (1998, p.127) gives the example, "'Lessons of another lost Arc for Britain' recalling the film title 'Raiders of the Lost Ark' (and referring to the French horse race 'Le Prix de L'Arc de Triomphe')."

Finally, Partington's fourth modification technique classification is rephrasing. He defines this as a technique whereby the original form is made almost unrecognizable to the reader. Partington (1998, pp.127-28), gives the following example: "England's biggest rugby union club are prepared to conquer at the Stoop in Saturday's semi-final [...]". Here, the phrase "conquer at the Stoop' recalls the original phrase 'She Stoops to Conquer', the title of the well-known play by Oliver Goldsmith, but the radical change in meaning, structure, and context obscures its original form almost completely.

Proverbs may undergo a semantic shift. This is mainly done in order to re-contextualise old proverbs in a new light or context. However, re-contextualising demands different categories to interpret it. This is relevant to this article, because it is useful to analyse how either obvious or more obscure cultural backgrounds flesh out the cultural life of $20^{\text {th }}$ century Syria in al-Mahmūd's narrative. Therefore, the relationship to tradition established by the usage of proverbs is not direct but mediated by forms of semantic change that problematize the cultural roots of modern Syrian society.

\section{The function of modified proverbs in literature}

As noted, proverbs within al-Mahmūd's narrative serve to flesh out material and cultural life in the first half of $20^{\text {th }}$ century Syria. This is achieved through the method of modification as both reception (rich cultural background, ancient roots) and adaptation (new context means new meaning, which can be either the same meaning revived or an ironical subversion of the original meaning). This view is supported by a number of critics, who argue that there is a purpose in using the modified form of the proverb instead of employing the original one. One of the functions is to serve a specific meaning in the context, where it seems odd to use the canonical proverb in this particular narrative space. The context may require clothing the proverb with new specific referents. Thus, in a certain situation and/or location in a literary text, the new proverb works perfectly, producing an occasional synonymous proverb (Martinez, 2006, 138). This point is reiterated by Naciscione (2010, p.41), who argues that Phraseological Units (PUs), such as proverbs, may appear in different forms or structures, and convey various meanings. Naciscione (2010), speaks of the "instantial use" (p.41) of PUs, which works when the reader makes a connection between the "base form of the PU and the textual reality" (Naciscione, 2010, p.41).

Szpila (2011) argues that when proverbs are placed in a literary context, it is relatively easy to play with their structure and meaning. He offers this explanation: "Obviously, literary language permits greater freedom in the creative manipulation of both the form and semantics of proverbs,

Arab World English Journal for Translation \& Literary Studies 
but the differences are perhaps only in quantity, not the quality of deployment" (p.173). Similarly, Martin (2011) argues that proverbs have the flexibility to adapt to the literary milieu of the text: "One of the most powerful social institutions that can be creatively modified in dystopian fiction is language, and within the vast linguistic realm, proverbs are particularly suitable for stylistic modification" (p.182). He also $(2011,185)$ argues that inventing new societies demands to find suitable new proverbs. Thus, in a literary work such as Huxley's Brave New World, whose main theme revolves around a dystopian society, the original proverbs cannot fit the context without adaptation. Martin (2011) explains this as follows: "Proverbs, for the most part, reveal themselves as optimal tools for dystopian writers, since they are ubiquitous elements in folklore and most other cultural phenomena worldwide. Their canonical form, however, belongs to a particular society with a particular culture in a specific period of history. If authors are to create a fictional society in the near future, they need new proverbs of their own" (p.185).

Martin (2011, p.186) examines the proverb in Brave New World uttered by the character Lenina: "A gramme in time saves nine", which is modified from the original proverb "a stitch in time saves nine". Here, Lenina replaces the lexeme "stitch" with the lexeme "gramme", because this seems more appropriate to the context. Lenina is advising the importance of taking a dose of a drug to deal with sleep problems. It is obvious that the canonical meaning of the proverb does not change, but interconnects with the new one. Martin (2011) states that the modified proverb is used by the author to fulfil a specific intention:

Of course, a stitch in time saves nine potentially applies to a wider range of situations than Huxley's creative exploitation of it. The fact that it is the canonical proverb which carries the most comprehensive meaning supports the argument that ad hoc modification usually performs a likewise ad hoc function such as supporting background information in the plot, as is the case here (p.186).

The discussion of the appropriateness of proverbs to certain contexts is as vital in al-Mahmūd's novel as it is in Huxley. Like Huxley, al-Mahmūd makes use of the lineal features of proverbs and أو لاد الحاره الثرقيه أكثر adjusts them in a way that suits his theme. For example, the adjusted proverb a awlād al-ḥāra al-ŝarqiyya akțar min al-ḥabb ${ }^{c}$ alā al-zētūn (The children of the eastern quarter are more than olives on the olive trees) is derived from the proverb in its original form أكثر من الهمّ على القلب (فريحة، 1953، ج1، صن06) (More than worries in the heart). This expresses abundance or fecundity. Al-Maḥmūd modifies this general proverb into a very specific form to serve this specific situation in the narrative. In this scene, the author pictures how boys go to the neighbour's olive grove and steal olives from the olive trees. Thus, he adds the words أو لاد الحاره الثرقيه (the children of the Eastern Quarter) at the beginning of the proverb. This is to emphasise a certain location in his village, which serves the overall theme of the novel, as being a realistic one. Moreover, because the situation is about the olive season, al-Mahmūd replaces the word هo هب (worries) in the original proverb with the word (olives) in the modified proverb, and the word قلب (heart) in the original proverb with the word زيتون (olive trees) in the modified proverb. This example emphasises the role of modified proverbs in fleshing out the culture.

Arab World English Journal for Translation \& Literary Studies 


\title{
3. Modified proverbs and their formation techniques in Muftaraq al-Matar
}

In this section, I will analyse modified proverbs in Yūsuf al-Maḥmūd's novel Muftaraq al-Mațar ('The Parting of the Rain'). Al-Maḥmūd is a superbly expressive writer. This is in part due to his prolific use of proverbs and modified proverbs in comparison to other Syrian novelists. The flux of proverbs and modified proverbs in this text illustrates the author's phraseological repertoire, especially his use of these phrases not only to ornament his literary work but as a thematic device to stress certain social and cultural aspects of the life as lived along the Syrian coastline and in its rural hinterland, after the Ottoman occupation and the French Mandate, or even to portray certain characters or events. This is reflected in the contextual meaning of the sample proverbs, which are listed below.

\subsection{Discussion of modified proverbs in Muftaraq al-Matar}

This section presents sixteen modified proverbs in Yūsuf al-Maḥmūd's novel. All the examples are taken from my thesis (Issa, 2014). Each set of four examples illustrates one of Partington's modification techniques. Further discussion will be provided on the operation of modification in each modified proverb.

\subsubsection{Examples of Partington's technique of rephrasing}

\section{Example 1: \\ Modified proverb:}

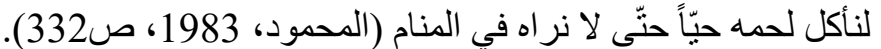 \\ Lina 'kula laḥmahu ḥayyan ḥattā lā narāhu fì al-manām
}

Let us eat his living flesh so that we do not dream of him!

Original proverb:

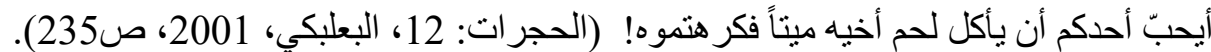

'a-yuhibbu 'ahadukum 'an ya'kula lahma 'axīhi mayyitan fa-karihtumūh!

Does one of you like to eat his dead brother's flesh when you have hated him!

\section{Discussion}

The modified proverb is an adapted form of the Qur'anic sura, which refers to the act of "snitching on others". However, the sense of the modified proverb is in sharp contrast to that of the original, which means: "to speak about a person while he is absent is not a good habit". The modified proverb is presented in the imperative mood and encourages "eating one's brother's flesh", while the original is in the interrogative, rhetorically indicating a rejection of this. The modified proverb also adds three words at the beginning a-yuhibbu ahadukum 'an. in addition, it substitutes the adjective hayyan, which means "alive", for the adjective mayyitan which means "dead". It substitutes another lexeme fa-karihtumūhu with hattā lā narāhu fi al-manām. Finally, it substitutes the two lexemes lahma axihi for the lexeme laḥmahu.

Arab World English Journal for Translation \& Literary Studies 
On the literal level, both proverbs deal with "eating human flesh". On the metaphorical level, the idea is backbiting and snitching - the modified proverb encourages backbiting, while the original one discourages people from it through the rhetorical use of the interrogative form. However, despite the reversal of the message in the modified proverb, the reader who has some knowledge of Islam can easily identify the original proverb. The writer has modified the original Qur'anic sura to fit the context of the situation and the conversation. In doing so, he has added a humorous flavour to the text and has given an idea about the habits and traditions of his milieu how men in his village spend their evenings gossiping about others or sharing news of the other villagers. The technique used is Partington's rephrasing. This modified proverb is antonymous to the original one.

\section{Example 2: \\ Modified proverb:}

Where did you melt away like salt?

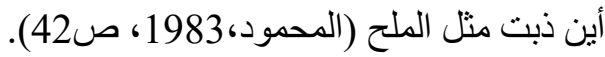

$$
\begin{aligned}
& \text { 'ayna dubti mițl al-milh }
\end{aligned}
$$

Original proverb:

$$
\begin{array}{r}
\text { فص ملح و داب (الأسود، 213). } \\
\text { Faṣs milh ū dāb. }
\end{array}
$$

(There was) a clove of salt but it dissolved.

Discussion

Both the modified proverb and the original mean "to disappear so quickly, just as salt dissolves in water". The modified proverb begins with the interrogative adverb أين 'ayna (where) and the past tense of the verb $\underline{d} \bar{a} b a$ (here in the form $\underline{d} u b$ ), plus the second person feminine singular suffix $-t i$. The verb form $\underline{d u b t i}$ is Standard Arabic, while in the original proverb the verb $d \bar{a} b$ is colloquial and occurs at the end of the proverb. The modified proverb ends with al-milh 'the salt' preceded by mitil, while the original proverb begins with milh without the definite article al 'the', but preceded by fașs, which is an amount of salt as small as the gem of the ring. The writer slightly modified the proverb to fit the context. However, although there is a change in the form of the original proverb, the modified proverb has not deviated from the overall metaphorical meaning of the original. According to Partington's classification, the technique used in this modified proverb is rephrasing. Moreover, this modified proverb is semantically similar to the original. The two proverbs can be regarded as synonymous.

Example 3:

Modified proverb:

$$
\begin{aligned}
& \text { لا تبحثي فيها عن نجوم الظّهر (المحمود، 1983، صaba }
\end{aligned}
$$

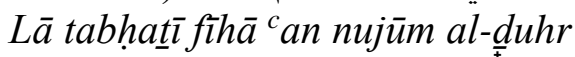

Do not look for the midday stars.

Original proverb:

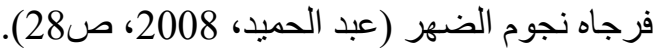

$$
\begin{aligned}
& \text { Farjāh njūm al-ḍihr }
\end{aligned}
$$

Arab World English Journal for Translation \& Literary Studies

ISSN: 2550-1542 | www.awej-tls.org 
I will show the midday stars, or By God, I will show you the midday stars.

Discussion

The context of this modified proverb is that the mother Xadra al- ${ }^{\mathrm{c}}$ Ali asks her daughter Xātūn to go to the water source and fill up the clay jug as soon as she can and without becoming distracted. The original proverb فرجاه نجوم الضهر farjāh njūm aḍ̂hr (he showed him the midday stars) means: 'to beat someone until they are unable to distinguish day from night'. In the modified proverb, there is advice and a warning - not to search for stars at midday in order not to be distracted from one's tasks, while the original proverb involves the threat of a beating that will make the person unable to distinguish day from night. The modified proverb is in the negative form, while the original in the affirmative. The original begins with the verb فرجاه farjāh (showed him), which is in the past tense and, in the original proverb, means '[he] tortured him'. 'Abd al-Hamīd's version (farjāh njūm al-dihr) is purely colloquial. The modified proverb begins with لا تبحثي فيها عن نجوم الظُهر (Do not look at it [the sky] for the midday stars). The remaining lexemes, nujūm ad-d 'the midday stars' are shared by both proverbs. But the lexeme ad-dihr (midday) is in Colloquial Arabic in the original proverb, while it is in Standard Arabic in the modified proverb: ad- $\underline{d} u h r$. The modified proverb is used in a similar way to the original, because it involves the threat of beating Xātūn in case she gets distracted from fulfilling her task. According to Partington's classification, the technique used in the modified proverb is rephrasing. The modified proverb is a synonym of the original one.

\section{Example 4:}

\section{Modified proverb:}

قاتل الله الجوع ما أكفره! (المحمود 1983 صakfarah!

Qātala al-lāh al-jūic mā 'akfarah!

TT

May God fight starvation for how it makes (the person) lose faith (in God)!

Original proverb:

If poverty were a man, I would kill him.

$$
\begin{array}{r}
\text { لو كان الفقر رجلاً لقتلته (قول للإمام علي) (الجعيثن، 2007). } \\
\text { Law kāna al-faqru rajulan la-qataltuh }
\end{array}
$$

\section{Discussion}

The context of the modified proverb is as follows: A pious man spent a night in a house in one of the local villages. When they offered him food, he did not like it. So, he went to sleep without eating anything. But later, at midnight, he woke up hungry, uttering this proverb. Both the original proverb and its modified version refer to severe poverty and hunger.

The original is attributed to the central Shia religious figure, Imam ${ }^{\mathrm{c}} \mathrm{Alī}$ Bin Abī Ṭālib (600 AD): الجعيثن، الف كان الفقر رجلاً لتلته law kāna al-faqru rajulan la-qataltahu (النه 2007). It means: "If poverty were a man, I would kill him". It expresses the concern that poverty may lead people to disbelief, and other sins - adultery, theft or even murder. The original proverb involves a nominal 
sentence. It begins with the conditional article law (if), followed by the imperfect verb $k \bar{a} n a$ (was), and الفقر al-faqru (poverty). This is substituted by the lexeme الجوع al-jü (hunger) in the modified proverb, followed by the interrogative article $m \bar{a}$ followed by a noun, ending with the object pronoun suffix - $h u$ (he) in أكفره akfarahu (how great an unbeliever is he). By contrast, in the original proverb al-faqru is followed by the predicate of the imperfect verb kanna, followed by the verb قتلته laqataltuhu (I would kill it). Here, the basic verb form two pronoun suffixes, $-t u$ 'I', expressing the subject and $-h u$ 'it', expressing the object. The verb with its subject and object are the apodosis (main clause) complementing the protasis (subordinate clause) in the first part of the conditional sentence. From this analysis, we notice that the new form of the proverb has a drastically different form to that of the original. According to Partington's categorisation, the technique used in the new form of the proverb is rephrasing. The modified proverb is in effect synonymous with the original one.

\subsubsection{Examples of Partington's technique of substitution \\ Example 1: \\ Modified proverb:

$$
\text { [أو لاد الحاره الشرقية] أكثر من الحب على الزيتون ( المحمود، 1983، ص 44). }
$$

[The children of the eastern quarter are] more than olives on the olive trees.

\section{Original proverb:}

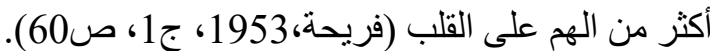

$$
\begin{aligned}
& \text { aktar min al-hamm calā al-qalb }
\end{aligned}
$$

[This thing is available in quantities] more than the heart's worries (Frayha, 1953, p.60).

\section{Discussion}

In the novel, the author describes how in the olive season children go to their neighbour's olive groves and steal the fruit. The original proverb is used to indicate the large number of preoccupations that perturb human beings. Similarly, the modified proverb describes the large number of children that come to disrupt and frustrate the farmers' hard work. The modified proverb substituted three lexemes $a l-h a b b,{ }^{c}$ ala and $a z-z \bar{e} t \bar{u} n$ for $a l$-hamm and ${ }^{c} a l-q a l b$. All the lexemes in both the original and the modified version belong to the same grammatical category. Both the proverb and its modified form express the same idea: abundance. Therefore, they are synonymous. The writer has made this slight change to the original proverb to fit the context better. According to Partington's classification, the technique used in the modified proverb is substitution.

\section{Example 2}

Modified proverb:

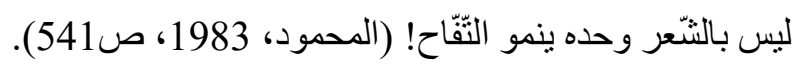

Laysa bi-al-sî̀ $r$ waḥdahu yanmū al-tuffāh

Apple trees cannot grow by poetry alone!

Arab World English Journal for Translation \& Literary Studies

ISSN: 2550-1542 | www.awej-tls.org 


\section{Original proverb:}

$$
\begin{aligned}
& \text { ليس بالخبز وحده يحيا الإنسان (متى:4:4). } \\
& \text { Laysa bi-l-xubz wahdahu yahyā al-insān }
\end{aligned}
$$

Man shall not live on bread alone (Matthew 4:4).

\section{Discussion}

The context of the original proverb is Jesus' period of fasting in the wilderness. In the Gospel of Matthew, Satan tried to tempt Jesus by mocking Him and telling Him that if He really was the Son of God, He should turn stones into bread; but Jesus replied that his sustenance came from God's words. The context of the modified proverb is that the character Musallim wonders whether his teacher's apple trees grow better than other neighbouring apple trees because their owner is a poet, as if reciting poems to them could encourage them to grow. The poet, however, rejects Musallim's speculation, by implicitly denying that his poetic words may have the same creative power as God's Word. Although the words $b i-\check{s}_{-} \check{S}_{i}{ }^{c} r i$, yanmū and at-tuffăh in the modified proverb replace the words of the original proverb, bi-l-xubz, yahyā and al-insān, the reader can recognize the original form of the modified proverb. Here the modification motivates the reader to think more about the sentence and ponder the original form. It catches the reader's attention and makes the modified proverb more effective in the narrative context because it highlights the sense of humour. The technique used is Partington's substitution. The two proverbs are antonyms of one other. In terms of Partington's classification, the technique used in forming this modified proverb is substitution.

\section{Example 3: \\ Modified proverb:}

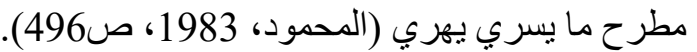

$$
\begin{aligned}
& \text { Mațraḥ mā yisrī yihrī }
\end{aligned}
$$

Wherever it passes, it harms.

\section{Original proverb:}

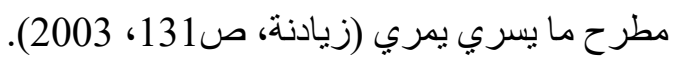$$
\text { Mațrặ mā yisrī yimrī }
$$

Wherever it passes, it comforts.

\section{Discussion}

Umm-Maḥmūd has slaughtered the only cockerel among many hens, and cooked it for her guest and future son-in-law Nibrās. As a consequence, the hens are "unhappy" about losing their sole male boss, the cockerel. Therefore, they wish for those who eat the cockerel's meat to suffer harm because of their unjust meal. Usually, the proverb مطرح ما بسري يمري matrah mā yisrī yimrī (wherever it passes, it comforts) is said by the host/hostess to a beloved guest, friend, or child when having his/her food. It is like a prayer that he/she may enjoy good health as a result of the meal. The lexeme yimri in the original proverb is substituted by the lexeme yihri in the modified one. Both the original and the substitute belong to the same grammatical category of $3^{\text {rd }}$ person,

Arab World English Journal for Translation \& Literary Studies 
masculine, imperfect verb. Both verbs describe the effect of food on the human body - either it harms when it is not digested properly or it brings health when it passes easily. In terms of Partington's classification, the technique used in this modified proverb is substitution. The modified proverb works as an antonym to the original one.

\section{Example 4: Modified proverb:}

It only sings as it likes.

\section{Original proverb:}

Each one sings as he like.

$$
\begin{aligned}
& \text { لا تغنّي إلّا لليلاها (المحمود } 1983 \text { ص 597a) } \\
& \text { Là tuğannī 'illā li-laylāhā }
\end{aligned}
$$

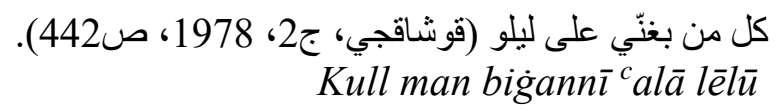

\section{Discussion}

Musallim says that people in his village gather to celebrate happy events such as weddings. This gives them a sense of autonomy and the feeling that life is worth living. This contrasts with their being oppressed by the landlord and the Beg. The proverb thus provides a metonymy of love and domesticity among people, and indicates that there is unity, love and good relations between people in this village. The original proverb is 'Each one sings as he likes'. This means, by contrast, that each person has his own individual opinion which is different from that of other people, thus indicating disparity, disunity and disorder. This is opposite to the meaning of the modified proverb. This modification of the original proverb acceptable and usable, without any objection.

The modified proverb begins with the negative particle $l \bar{a}$, unlike the original one. The colloquial verb bigannī is replaced by the Standard Arabic verb tugannī in the modified proverb, with the preposition min deleted. The preposition ${ }^{c} a l \bar{a}$ is substituted by the preposition $l i$, preceded by the added exceptive particle ill $\bar{a}$ 'except' with the pronoun suffix $-h \bar{a}$ added to the end of the lexeme to become li-laylāha , which is Standard Arabic, while lēlu is colloquial Arabic. Here the writer does not use the original colloquial Arabic form of the proverb, despite the fact that this colloquial form is more in keeping with the peasants' milieu. Rather, it seems that the narrator uses the form which he does on purpose, in order to show that Musallim is an educated man. In the modified proverb, there is a sense of unity among the villagers, while in the original there is a sense of disunity. In this case, the modified proverb works as an antonym of the original. In terms of Partington's classification, the technique used in this modified proverb is substitution.

\subsubsection{Examples of Partington's technique of abbreviation}

\section{Example 1: \\ Modified proverb:}

$$
\text { الجمل لا يرى حردبته (المحمود، 1983، ص 40). }
$$


The camel does not see his hunched back.

\section{Al-jamal lā yarā ḥirdabbatahu}

\section{Original proverb:}

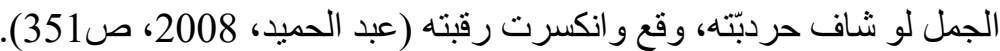

$$
\begin{aligned}
& \text { Al-jamal law šâf hirdabbtuh, wiqi }{ }^{c} \bar{u} \text { inkasrit raqubtuh }
\end{aligned}
$$

Had the camel seen its hump it would have fallen and broken its neck.

Note that of the four original forms of the proverb found in various sources I have chosen the one which is most commonly used on the Syrian coast.

\section{Discussion}

Xaḍrā al- ${ }^{\mathrm{c}} \mathrm{Al} \overline{\mathrm{i}}$ addresses this proverb to her husband, who claims that Xātūn's curly hair is lovely. This means that Abā Mahmūd does not see this deficiency in his daughter, exactly as the camel cannot see the hump on his own back which shows the ugliness of his uneven body. Looking at 'abd al-Hamīd's original proverb, we notice that it is more extensive and expressed as a conditional form. The modified proverb is in the negative form and is an abbreviated version of the originalit mentions only the first half of the original proverb, with a slight substitution. In the modified proverb the lexemes $l \bar{a}$ and yara are substituted for the lexemes law and $\check{s} \bar{a} f$. The verb $\check{s} \bar{a} f$ in the original proverb is in the past tense and in Colloquial Arabic, while the verb yara is in the present tense and in Standard Arabic in the modified proverb. It is easy for the reader to recall the original proverb. In this case, the modified proverb and its original are synonyms. According to Partington's classification, the modified proverb uses the abbreviation technique.

\section{Example 2:}

Modified proverb:

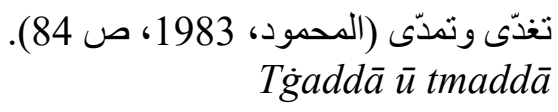

Have lunch and then lie down.

Original proverb:

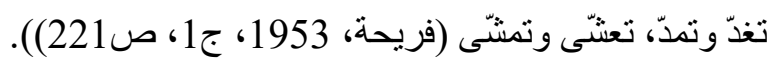

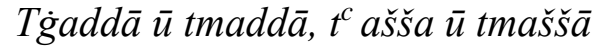

Have lunch and lie down, have dinner and take a walk.

\section{Discussion}

This is what Musallim and his brother, Abū Myzīad, say to their cousin, Habīb, when he asks them to go back to work immediately after their lunch rather than taking a rest. The proverb means that a man should take a rest after having his lunch and not return to work immediately.

The modified proverb is in an abbreviated form of the original- it mentions only the first half of the original proverb, with a slight substitution. The lexemes $t^{c} a \check{s} \check{s} \bar{a}$ and $t m a \check{s} \check{s} \bar{a}$ are omitted in the modified proverb. In terms of Partington's classification, the modified proverb uses the

Arab World English Journal for Translation \& Literary Studies 
abbreviation technique. However, the modified proverb and the original are synonyms, because they both recommend healthy eating habits.

\section{Example 3:}

Modified proverb:

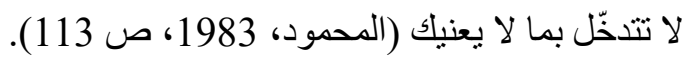

Là tatadaxxal bimā lā ya $a^{c} \bar{\imath} k$

Do not interfere in what is not your business.

Original proverb:

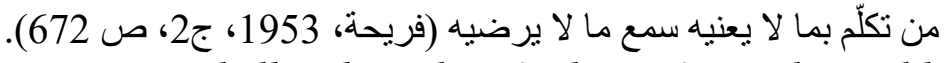

$$
\begin{aligned}
& \text { Man takallam bimā lā ya }{ }^{c} \text { nìh samic a mà là yurḍ̄h }
\end{aligned}
$$

Those people who talk about things that aren't their business will hear things that they're not happy with.

\section{Discussion}

Zainab's husband asks his wife why the two brothers, Abu Miyzād and Musallim, came to his house. But Zainab asks him not to interfere in the matter. She utters this proverb in order to point out her contempt for her husband: this is not his concern and he should not bother about it. The modified proverb is an abbreviated form of the original - it mentions only the first half of the original proverb, with a slight substitution. The modified proverb is in the form of a prohibition. The lexemes $l \bar{a}$ and tatadaxxal are a substitute for man and takallama at the beginning of the original proverb. However, the most obvious change in the modified proverb is the omission of the second part of the original: $s a m i^{c} a m \bar{a} l \bar{a}$ yurḍihh. According to Partington's classification, the modified proverb uses the abbreviation technique. Here, the modified proverb and the original can be regarded as synonyms.

\section{Example 4: Modified proverb:}

$$
\text { تعشيت وتمشيت (المحمود، 1983، ص 209). }
$$
$t^{c} a \operatorname{šs}^{2} \bar{t} \bar{u}$ tmašše $\bar{t}$

I had my supper and went for a walk.

\section{Original proverb:}

$$
\begin{aligned}
& \text { تعشّ وتمشّ، تغذّ وتمد (فريحة، 1953، ج2، ص ص }
\end{aligned}
$$

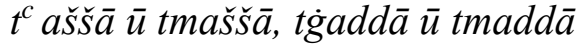

Have supper and take a walk, have lunch and lie down.

\section{Discussion}

The modified proverb is in an abbreviated form of the original - it mentions only the first half of the original proverb, with a slight substitution. The modified proverb uses verbs in the past tense, with the first-person singular suffix $-t$ on both lexemes in the modified proverb. By contrast, the 
original proverb takes the form of a piece of advice. It is also more extensive than the modified one, with the extra words $\operatorname{tg} a d d \bar{a}, \bar{u}$ and tmadd $\bar{a}$. According to Partington's classification, the modified proverb uses the abbreviation technique. The modified proverb and the original are synonyms.

\subsubsection{Examples of Partington's technique of insertion}

\section{Example 1:}

Modified proverb:

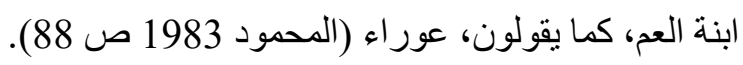

$$
\begin{aligned}
& \text { Ibnat al- }{ }^{c} \text { amm, kamā yaqūlūn, ' }{ }^{c} \text { awrā } \text {, }
\end{aligned}
$$

The cousin, so they say, is one-eyed.

\section{Original proverb:}

$$
\begin{array}{r}
\text { بنت العم عورة (شقير، 1995، صint alcamm }{ }^{c} \text { awra } \\
\text { Bint). }
\end{array}
$$

The cousin is one-eyed.

\section{Discussion}

Habīb, Musallim's cousin, says that $\mathrm{Sa}^{\mathrm{c}} \mathrm{da}$, Habīb's brother's wife, is only good for singing at weddings. Then Kafa says: "Ask your God to have a woman like her", quoting to him the proverb ibnat al- ${ }^{c} a m m$, kamā yaqūlūn, ${ }^{c} a w r \bar{a}$ (the cousin, as they say, is one-eyed). Kafa's point is that a person we are familiar with is always underestimated. People do not recognize her virtue and beauty, as if she was one-eyed. They prefer the stranger over her, even if that stranger is inferior to her in beauty and morals.

The two proverbs can be regarded as synonymous. The modified proverb has two extra elements, كما يقولون kamā yaqūlūn (so they say), but this addition is merely emphatic and does not affect the meaning of the original. The modified proverb is Standard Arabic while the original is colloquial. Both proverbs have the same metaphorical meaning. According to Partington's classification, the modified proverb uses the insertion technique.

\section{Example 2:}

Modified proverb:

$$
\text { لكن صوفتي أنا حمر اء (المحمود } 1983 \text { ص 115). }
$$
Lākin șūftī 'anā ḥamrā'

But my own wool is red

Original proverb:

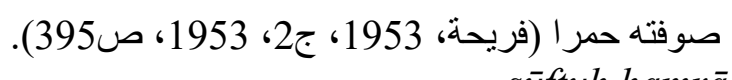

His wool is red

$$
\text { șüftuh ḥamrā }
$$

Arab World English Journal for Translation \& Literary Studies

ISSN: 2550-1542 | www.awej-tls.org 


\section{Discussion}

Sheikh Mahmūd says that he does not have any luck with his aunt's family, because they do not love him, no matter how faithfully he works for them. He refers to the proverbial redness of wool to indicate that he is not loved by people, but regarded with suspicion. In Syrian culture, "a person's wool is red" is said in order to indicate that an individual is unloved and untrustworthy. The modified proverb has two extra elements, lākin at the beginning and 'an $\bar{a}$ in the middle. There is also a slight substitution in the modified proverb, which consists in the addition of the (s) hamza to the word "hamra" " and the substitution of $-\bar{l}$ for $-h$ (to change from "his" to "my"). However, this addition does not alter the meaning. The modified proverb is in Standard Arabic, while the original one is in colloquial. The two proverbs can be regarded as synonymous, but the modified one is more emphatic. According to Partington's classification, the modified proverb here uses the insertion technique.

\section{Example 3:}

Modified proverb:

$$
\begin{aligned}
& \text { ايه، عيش، يا كديش، حنّى يأتيك الحشيش (المحمود } 1983 \text { ص صath }
\end{aligned}
$$

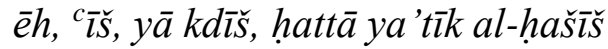

Eh, donkey, live, till the grass comes to you

Original proverb:

$$
\begin{aligned}
& \text { عيش يا كديش تا ينبت الحشيش (عبد الحميد، 2008، ص49a }
\end{aligned}
$$

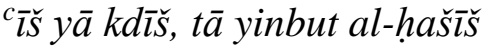

Live, you donkey, till the grass grows.

\section{Discussion}

The original proverb conveys a sense of procrastination and uncertainty: "when someone makes a promise, no one knows if she or he will keep it". The pessimistic implication is that the promise will not be kept. The modified proverb has one extra lexeme $\bar{e} h$ at the beginning, which emphasises procrastination. There is also a slight substitution in the modified proverb, in the replacement of the word $t \bar{a}$ in the original with hattā. Another slight substitution is the use of the word $y \bar{a}$ 't $\bar{k} k$ in the modified proverb, replacing yinbit in the original. According to Partington's classification, the modified proverb uses the insertion technique. The original proverb and its modified version have the same meaning.

\section{Example 4:}

Modified proverb:

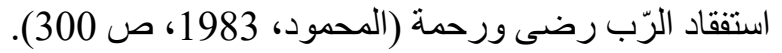

Istifqā al-rabb rị̣̄ $\bar{u}$ raḥmih

God's trial is contentment and mercy.

Original proverb:

$$
\text { استفقاد الرّب رحمة (عبد الحميد، 2008، ص15abb rahr). }
$$

Istifqād al-rabb raḥmih 
God's trial is mercy.

Discussion

Illness took away the lives of many young men and women in the village. Therefore, the villagers, who believe in Fate and God's will, surrender to their sorrows and grief by quoting this proverb. This is a proverb that references a specific Islamic subculture. It is usually said when a person is put into a difficult position, whether this health-related or financial, or even encountering death. This is mainly because those who have faith believe that everything is predestined and that Allah has the ultimate power over everything. The modified proverb is an expanded version of the original. In the modified proverb, we find the insertion of the lexemes rid $\bar{a}$ and $\bar{u}$. The rest of the modified proverb is similar to the original. However, this addition strongly emphasises the message of the original proverb. Therefore, the two proverbs are synonyms. According to Partington's classification, the technique used in the modified proverb is insertion.

\section{Semantic relationship of modified proverbs to original proverbs in Muftaraq al-Matar}

I have applied Partington's analysis of the four techniques of modification to sixteen examples. The first four cases illustrate the semantic effects of Partington's rephrasing technique on modified proverbs. We can observe here that one modified proverb is an antonym of its original, and three are synonyms. In the case of modified proverbs which involve Partington's substitution technique, the modified proverbs stand in only two different semantic relationships with their original proverbs: three are antonymous and one is synonymous. By contrast, the third group of modified proverbs, which involve Partington's abbreviation technique, are all synonymous with their original proverbs, as are the last four examples, which involve Partington's insertion technique. In these cases, the additional words in the modified proverbs merely function to provide a more emphatic statement of the message conveyed by the proverbs, but do not alter their fundamental meaning.

\section{Conclusions}

The novel under investigation in this paper employs a large number of proverbs and modified proverbs. The study of the sixteen examples chosen shows diversity in the use of Partington's four types of modification techniques. These examples illuminate different semantic relations between the modified proverbs and their corresponding originals: synonymy and antonymy. The great majority of the modified proverbs, thirteen out of sixteen, preserve the meaning of the original proverb. However, a few of the modified proverbs give an opposite meaning to that of the original. This is the case in three of the modified proverbs involving Partington's substitution technique, and one of the proverbs involving his rephrasing technique. The four examples that use Partington's insertion technique also convey a more emphatic message.

Yūsuf al-Maḥmūd makes abundant use of proverbs and modified proverbs in Muftaraq alMatar. Such traditional formulas provide a strong expressive tool for the author to describe how characters communicate with each other, to depict the life of Syrians under the French colonial mandate, and to adapt a generic cultural background to a specific narrative situation. With great compositional skill, the writer creates a tapestry involving both tradition and innovation, deploying

Arab World English Journal for Translation \& Literary Studies 
different proverbs from various religious and folkloric sources and reshaping them to suit his own narrative. In this way, his prolific and creative usage of proverbial popular wisdom serves to express the complex relation of modern Syria to its cultural roots, combining affectionate traditionalism and ironic innovation.

\section{About the Author:}

Huwaida Issa is a visiting scholar at the University of Leeds. She got her PhD in Arabic Literature under the supervision of professor James Dickins at the University of Leeds in the UK. Her thesis researched proverbs, modified proverbs and curses in two Syrian novels. She got an MA in Literary Criticism, a Higher Diploma and a BA in English Language and Literature.

\section{References}

Bible Gateway. https://www.biblegateway.com/passage/? search=Matthew+4\%3A4\&version=NIV [Accessed 28 September 2018].

English Oxford Dictionary. https://en.oxforddictionaries.com/definition/us/lexeme [Accessed 23 May 2017].

Fernando, C. (1996). Idioms and idiomaticity. Oxford: Oxford University Press.

Honeck, R. (1997). A Proverb in Mind: the Cognitive Science of Proverbial Wit and Wisdom. Mahwah, New Jersey: Lawrence Erlbaum Associates.

Issa, H. J. (2014) Proverbs, Modified Proverbs and Curses in Two Novels of the Syrian Coast. $\mathrm{PhD}$ thesis, University of Leeds.

Litovkina, A.T. \& Mieder, W. (2006). Old Proverbs Never Die, They Just Diversify. Burlington: University of Vermont.

Martín, G. (2011). 'Proverb Modification in Aldous Huxley’s Brave New World'. Paremia. (20), 179-190.

Martinez, F. (2006). 'Occasional Phraseological Synonymy'. International Journal of English Studies, 6 (1), 131-158. Available at: http://revistas.um.es/ijes/issue/view/4781 [Accessed 16 December 2016].

Mieder, W. (2004). Proverbs: A Handbook. Westport: Greenwood Publishing Group, Inc.

Mieder, B., \& Mieder, W. (2004). 'Tradition and Innovation: Proverbs in Advertising'. The Journal of Popular Culture, 11 (2), 308-319.

Naciscione, A. (2010). Stylistic Use of Phraseological Units in Discourse. Amsterdam/Philadelphia: John Benjamin Publishing.

Naciscione, A. (2001). 'Phraseological Units in Literary Discourse: Implications for Teaching and Learning'. Riga/ Latvia: Latvian Academy of Culture. CAUCE (24), 53-67.

Net Bible. Matthew 4. http://biblehub.com/net/matthew/4.htm [Accessed 30 Jan 2017].

Partington, A. (1998). Patterns and Meanings: Using Corpora for English Language Research and Teaching. John Benjamin Publishing Company: Amsterdam/Philadelphia.

Szpila, G. (2011). 'Literary Paremic Loci in Salman's Rushdie's Novels'. Studia Linguistica Universitatis Iagellonicae Cracoviensis 171-177. http://www.filg.uj.edu.pl/documents/41616/8969068/12812-Szpila.pdf [Accessed 23 May 2017].

Arab World English Journal for Translation \& Literary Studies 
Zaikauskiené, D. (2012). Lietuvių Paremijos XX-XXI a. Sandūroje: tradicija ir inovacija (Lithuanian Paremias at the Turn of the 20th-21st Centuries: Tradition and Innovation). PhD thesis. Vilnius University.

\section{Arabic printed and electronic sources}

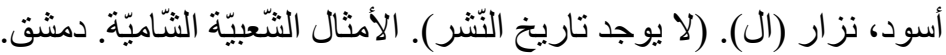

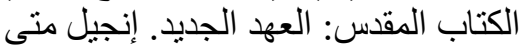

https://st-takla.org/pub_newtest/Arabic-New-Testament-Books/01-Matthew/Engeel-

Matta_Chapter-04.html [Accessed 28 September2018].

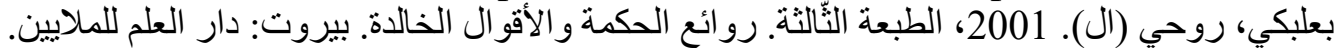

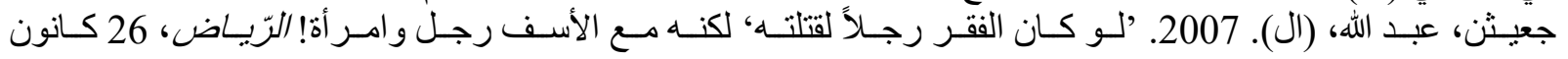

Available at (http://www.alriyadh.com/219556) [Accessed 03 October2014].

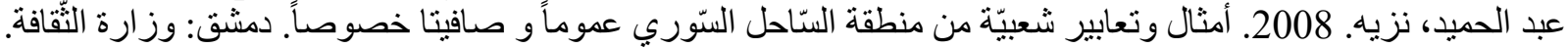

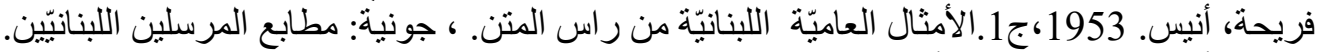

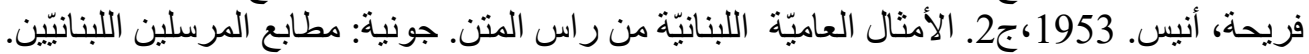

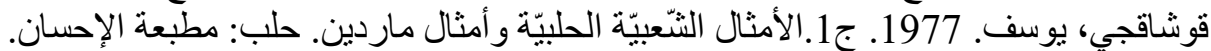

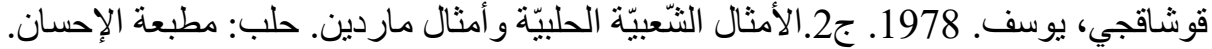
محمود، أحمد يوسف (ال). 1983. مفترق المطر . ، ، دمثق: اتحاد الكتّاب العرب. 